\title{
Application of Donnan Dialysis Coupled to Adsorption onto Activated Alumina for Chromium (VI) Removal
}

\author{
I. Marzouk $^{1,2}$, L. Chaabane ${ }^{2}$, L. Dammak ${ }^{2}$, B. Hamrouni ${ }^{*}$ \\ ${ }^{1}$ U.R. Traitement et Dessalement des Eaux, Faculté des Sciences de Tunis, Université de Tunis El Manar, \\ Tunis, Tunisia \\ ${ }^{2}$ Institut de Chimie et des Matériaux Paris-Est, UMR 7182 CNRS-Université Paris-Est Créteil, \\ Thiais, France \\ Email: *bhamrouni@gmail.com
}

Received June 16, 2013; revised July 16, 2013; accepted July 31, 2013

Copyright (C) 2013 I. Marzouk et al. This is an open access article distributed under the Creative Commons Attribution License, which permits unrestricted use, distribution, and reproduction in any medium, provided the original work is properly cited.

\begin{abstract}
The aim of this paper is the assessment of Donnan dialysis coupled to adsorption process for the removal of chromium from aqueous solutions. This study was conducted in order to benefit from each process, and it was an original and new combination. The coupling was a solution to improve the contact time and the amount of chromium (VI) removed. The coupling was successfully performed with $90 \%$ of chromium (VI) removed after 6 hours.
\end{abstract}

Keywords: Donnan Dialysis; Chromium (VI); Anion-Exchange Membrane; Adsorption; Activated Alumina

\section{Introduction}

One of the heavy metals that have been of major concerns in water and wastewater treatment is chromium. Its hexavalent form has been considered to be more hazardous due to its carcinogenic properties [1]. The chromium $(\mathrm{Cr})$ is widely used in various industrial applications leading to an increase in $\mathrm{Cr}$ concentration in water (industrial discharges), air (coal combustion), and soils (waste disposal). Chemical, leather and textile manufacturing, electropainting and chromium plating are the main human activities leading to an increase in $\mathrm{Cr}$ (VI) concentrations in the environment. Chromium has been considered as one of the top 16th toxic pollutants and because of its carcinogenic and teratogenic characteristics on the public, it has become a serious health concern [2]. Therefore, it is necessary to eliminate $\mathrm{Cr}$ (VI) from the environment in order to prevent the deleterious impact on ecosystem and public health. Because of the stricter environmental regulations, a cost effective alternate technology for the treatment of $\mathrm{Cr}$ (VI) contaminating wastewater is highly desired in the industrie. There are several treatment technologies available to remove $\mathrm{Cr}$ (VI) from wastewater such as chemical precipitation [3], ion-exchange [4-9], membrane process, as reverse osmosis and ultrafiltration [10-13], flotation [14], electrocoagulation [15], solvent extraction [16], reduction [17],

\footnotetext{
${ }^{*}$ Corresponding author.
}

dialysis or electrodialysis [18] and adsorption [19-24]. The adsorption of chromium (VI) onto different types of adsorbents, such as activated carbon, activated alumina, peat, leaf mould and wheat bran, has been studied and showed a good affinity with chromium and high amount of removal [19-23]. The Donnan dialysis is a useful membrane process used to recover valuable ions and remove undesirable ones from some waste effluents [24-32]. The theory and principles behind the Donnan dialysis process are recently reviewed by Luo et al. [33]. A number of fundamental and experimental studies have been conducted including treatment of alkali, alkali earths, transition and rare metals [34-39].

The idea of chromium (VI) removal by Donnan dialysis application coupled to adsorption onto activated alumina was performed in order to benefit from each one. This jointed process has never been done before. Accordingly, the present study deals with a new and original application of Donnan dialysis coupled to adsorption onto activated alumina in order to improve the removal of chromium (VI).

\section{Experimental}

\subsection{Material and Methods}

\subsubsection{Membranes}

For the Donnan dialysis process two AEMs have been used: Selemion ${ }^{\circledR}$ AMV and Neosepta ${ }^{\circledR}$ AFN. The AFN 
membrane was generously provided by Eurodia Industries S.A. and the AMV one was purchased from ASAHI GLASS. Details of their chemical structure are not disclosed, however, they do contain quaternary amine functional groups and their properties are listed in Table $\mathbf{1 .}$

Prior to any measurement, it was necessary to condition the samples in order to stabilize their physicalchemical properties and remove any impurities that may come from their manufacturing process. The French standard NF X 45 - 200 was followed to achieve this treatment [40]. It consists in immersing the samples of 10 $\mathrm{cm}^{2}$ in solutions of different natures. We started immersing the sample in $0.1 \mathrm{M} \mathrm{HNO}_{3}$. It was rinsed with water and dried with filter paper, then immersed for one hour in $\mathrm{HCl} 0.1 \mathrm{M}$ and rinsed by immersing in $\mathrm{NaCl} 0.1 \mathrm{M}$. The procedure was repeated twice and finally, the membrane was conserved in $\mathrm{HCl} 0.1 \mathrm{M}$ for $24 \mathrm{H}$.

\subsubsection{Activated Alumina}

The granular activated alumina used was supplied by Sigma-Aldrich (particle size spherical 150 mesh, pH (in the water) 4.5 , melting point $2040^{\circ} \mathrm{C}$, molecular weight $101.96 \mathrm{~g} \cdot \mathrm{mol}^{-1}$, pore diameter $58 \AA$ and surface area 155 $\left.\mathrm{m}^{2} \cdot \mathrm{g}^{-1}\right)$. It was dried at $110^{\circ} \mathrm{C}$ for $24 \mathrm{~h}$ in order to eliminate the impurities and to prepare the activated alumina.

\subsubsection{Reagents}

The stock solutions of chromium (VI) were prepared by dissolving sodium chromate salt $\left(\mathrm{Na}_{2} \mathrm{Cr}_{2} \mathrm{O}_{7}\right)$ in 1 liter of distilled water to have an initial concentration of $\mathrm{Cr}$ (VI) $1.00 \mathrm{~g} \cdot \mathrm{L}^{-1}$. All other reagents used were analytical reagent grade.

\subsubsection{Donnan Dialysis}

The Donnan dialysis is an ion-exchange membrane separation process in which ions of the same electrical charge are exchanged between two solutions through an ion-exchange membrane [41]. The Donnan dialysis is a continuous low energy process, requiring only few and simple chemicals and a workforce that can be unskilled.

Table 1. Properties of the two anion-exchange membranes used in this study.

\begin{tabular}{ccc}
\hline Parameter & Selemion $^{\circledR}$ AMV & Neosepta $^{\circledR}$ AFN \\
\hline Type & Homogeneous & Homogeneous \\
Structure property & PS/butadiene & PS/DVB \\
Fixed ionic group & $-\mathrm{NR}_{3}{ }^{+}$ & $-\mathrm{NR}_{3}{ }^{+}$ \\
$\begin{array}{c}\text { Ion-exchange capacity } \\
\text { (mmol-g }{ }^{-1} \text { ) }\end{array}$ & 1.85 & 3.15 \\
$\begin{array}{c}\text { Water content (\%) } \\
\text { Thickness (mm) }\end{array}$ & 19.9 & 40.5 \\
\hline
\end{tabular}

All meant that this process is very economical, can be implemented quickly even at remote locations.

We prepared one-component solutions containing $\mathrm{NaCl}$ the concentration of $0.1 \mathrm{M}$ (the receiver). As the feed compartment we used the $\mathrm{Cr}$ (VI) solution with the concentration of $100 \mathrm{mg} \cdot \mathrm{L}^{-1}$. The process was conducted in the laboratory set-up for dialysis, which comprised 2 compartments separated by AEM.

The samples were analyzed for residual Cr (VI) concentration by reaction with 1.5-diphenylcarbazide followed by absorbance measurements at $540 \mathrm{~nm}$ using a UV-visible spectrophotometer. This method was validated in a previous study [43].

The removal rate of chromium was calculated by Equation (1):

$$
\mathrm{Y}_{\mathrm{Cr}}(\%)=\frac{\mathrm{C}_{0}-\mathrm{C}_{\mathrm{e}}}{\mathrm{C}_{0}} \times 100
$$

where $\mathrm{C}_{0}$ and $\mathrm{C}_{\mathrm{e}}$ are the initial and equilibrium $\mathrm{Cr}$ (VI) concentrations $\left(\mathrm{mg} \cdot \mathrm{L}^{-1}\right)$.

Figure 1 shows the device used to study the chromium (VI) removal by Donnan Dialysis. It is composed of a thermoregulated water bath $\left(25.0^{\circ} \mathrm{C} \pm 0.1^{\circ} \mathrm{C}\right)$, containing a cell with feed and receiver compartments separated by an anion-exchange membrane. The solutions are pumped through the cell with a peristaltic pump fitted with a pair of identical heads and a speed variator allowing for variable flow rates. The hydrodynamic conditions on both sides of the membrane can be adjusted by two variable speed stirring rods. The dialysis cell consists in two detachable compartments made with polymethylmetacrylate (plexiglass). It is composed of four parts joined by three stainless steel treaded rods. The centring is assured by bolsters.

The two central compartments, consisting of two tubes are symmetrical. Two threaded holes penetrate each compartment and serve as supports for introducing and circulating solution in the compartment. The membrane is sandwiched between these two compartments, making a seal at the same time [42].

To supply the receiver compartment a $\mathrm{NaCl}$ solution is used at the concentration of $0.01 \mathrm{M}$ or $0.1 \mathrm{M}$. The feed compartment is filled with Chromium (VI) solution at the concentration of $100 \mathrm{or} 300 \mathrm{mg} \cdot \mathrm{L}^{-1}$.

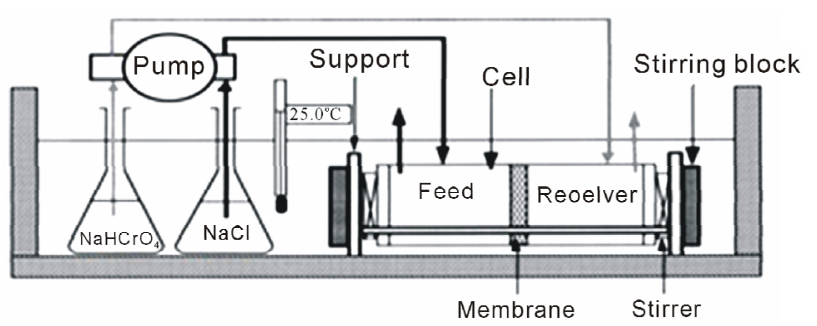

Figure 1. The experimental device of the Donnan dialysis process. 


\section{Results and Discussion}

\subsection{Donnan Dialysis}

Figure 2 shows the amount of chromium (VI) removed in the receiver compartment, for AFN membrane during 24 hours. In these conditions, only $10 \%$ of the chromium was removed, then after 24 hours the concentration grew-up to $20 \mathrm{mg} \cdot \mathrm{L}^{-1}$. Concerning the AMV membrane, the concentration of chromium remained constant during the 24 hours up to $7 \mathrm{mg} \cdot \mathrm{L}^{-1}$. The differences between the concentrations of chromium (VI) obtained can be explained by the difference in the ion-exchange capacity and the water content as shown in Table 1. So we can conclude that AFN membrane is more suitable than AMV membrane for the Donnan dialysis process.

The amount of chromium (VI) removed by the Donnan dialysis was determined on the basis of the following parameters: initial chromium concentration, type the anion-exchange membranes, $\mathrm{Cl}^{-}$concentration and magnetic stirring. The experiments have been carried out using a $2^{4}$ full factorial design to study the effect of the main and interaction parameters. The study allowed us to find the best conditions to remove the chromium (VI) by Donnan dialysis. These conditions were obtained in previous study $\left(\left[\mathrm{Cr}(\mathrm{VI})=100 \mathrm{mg} \cdot \mathrm{L}^{-1} ;\left[\mathrm{Cl}^{-}\right]=0.1 \mathrm{~mol} \cdot \mathrm{L}^{-1}\right.\right.$; AFN and high speed of magnetic stirring) and will be used for this study in order to improve the efficiency of this process for the removal of chromium [44].

\subsection{Adsorption onto Activated Alumina}

Adsorption is a highly effective process for a variety of applications such as removal of metal ions from wastewaters and it is considered one of the most efficient and fast methods to remove impurities. However, the elevated cost of activated alumina and the regeneration are its disadvantages. Adsorption experiments were carried out in mechanically agitated in a thermostatically bath, the beakers containing $100 \mathrm{~mL}$ of chromium with initial

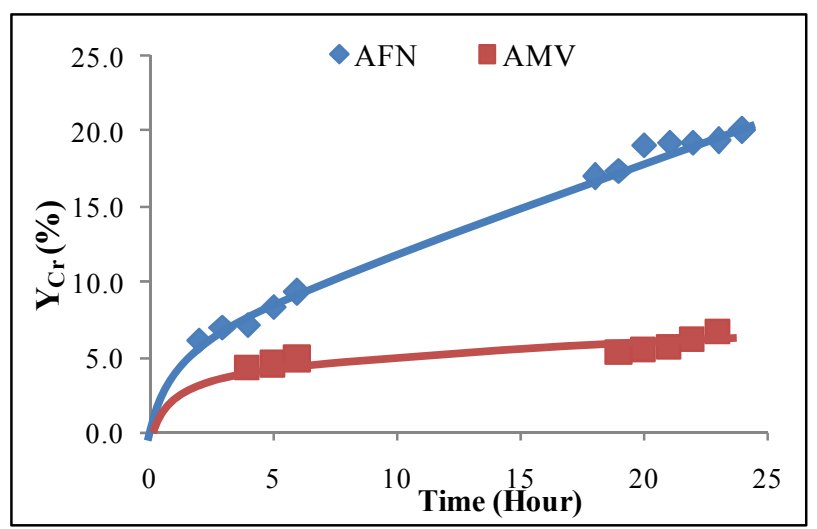

Figure 2. The amount of chromium (VI) removed by Donnan dialysis using AFN and AMV membranes. concentration $100 \mathrm{mg} \cdot \mathrm{L}^{-1}$ and with different amount of activated alumina from 1 to $10 \mathrm{~g}$, for $90 \mathrm{~min}$ and at $25^{\circ} \mathrm{C}$ [43]. The content was agitated with a constant stirring rate at $140 \mathrm{rpm}$. Samples were withdrawn after a definite time interval and filtered through Whatman $\mathrm{N}^{\circ} 1$ filter paper $(0.45 \mu \mathrm{m})$. In Figure 3, results show that the opti-

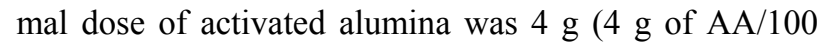
$\mathrm{mg} \cdot \mathrm{L}^{-1}$ of initial concentration of $\mathrm{Cr}$ (IV)). The fastness and the efficiency of this process were the advantages of activated alumina, but its major inconvenient was the cost.

\subsection{Donnan Dialysis Coupled to Adsorption onto Activated Alumina}

In order to improve the amount of chromium (VI) removed by Donnan dialysis and reduce the experimental time, we have tested for the first time the Donnan dialysis process coupled to the adsorption onto activated alumina. First, experiments were performed with 0.1 $\mathrm{mol} \cdot \mathrm{L}^{-1}$ of $\mathrm{NaCl}$ solution only in the receiver compartment, and $100 \mathrm{mg} \cdot \mathrm{L}^{-1}$ of initial chromium concentration. Then the dose of activated alumina $1 \mathrm{~g}$ was added, even the optimal dose was $4 \mathrm{~g}$, we choose to reduce the amount of activated alumina, as shown by the schematic flow of in Figure 4.

Figure 5 shows the amount of chromium (VI) removed in the feed compartment during 6 hours in two cases: without (ם) and with DD-AAA coupling $(\boldsymbol{\nabla})$. It is noteworthy, an imminent increase of $86 \%$ of chromium (VI) removed when the activated alumina was added, this can be explain by the fact that chromium (VI) was adsorbed onto activated alumina in the receiver compartment so the Donnan dialysis kinetics increased.

Figure 6 shows the amount of chromium (VI) remained free in the receiver compartment after passage through the anion exchange membrane. It should be noted that despite the large amount of chromium (VI) that happens in the case of a coupling DD-AAA $(90 \%$

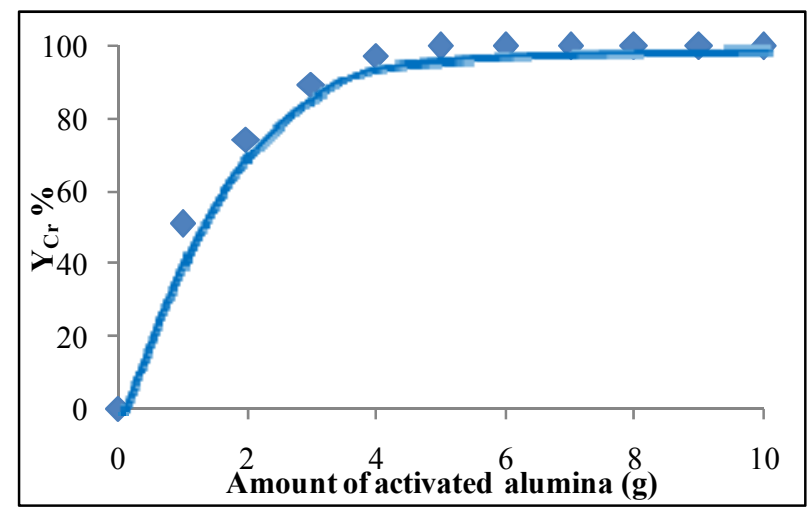

Figure 3. Effect of adsorbent dose on chromium (VI) removal. 


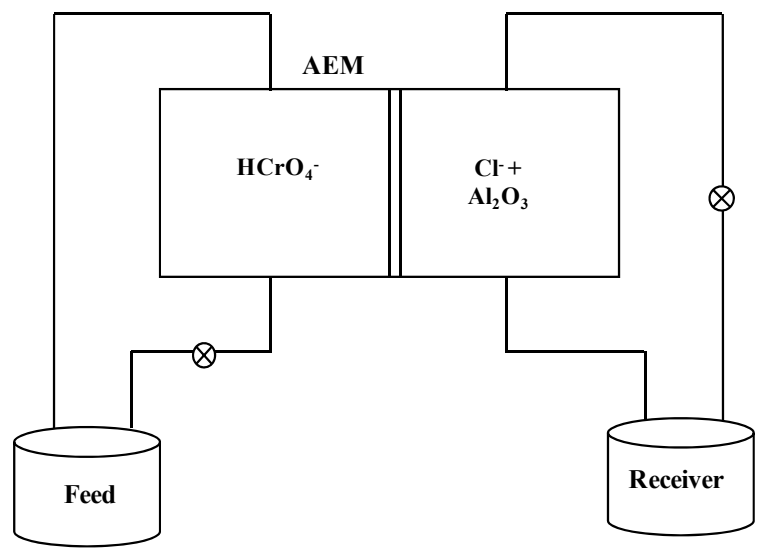

Figure 4. Schematic flow diagram of Donnan dialysis system coupled with activated alumina.

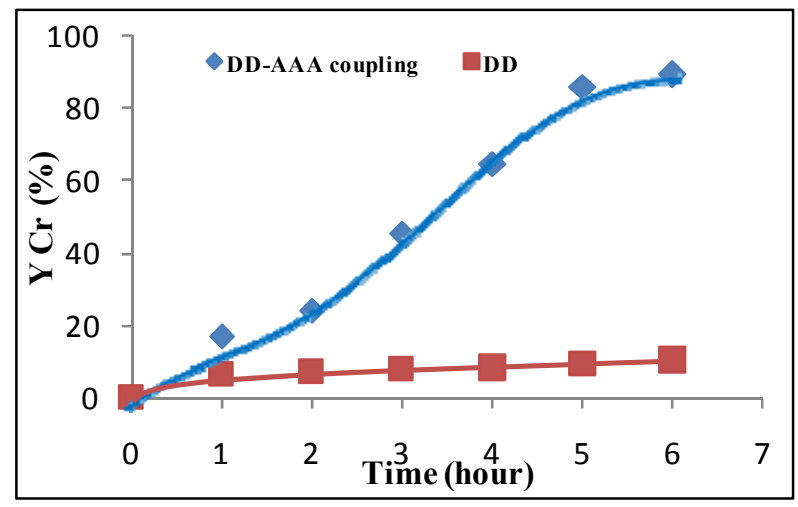

Figure 5. Amount of the chromium (VI) removed in the feed compartment with and without DD-AAA coupling.

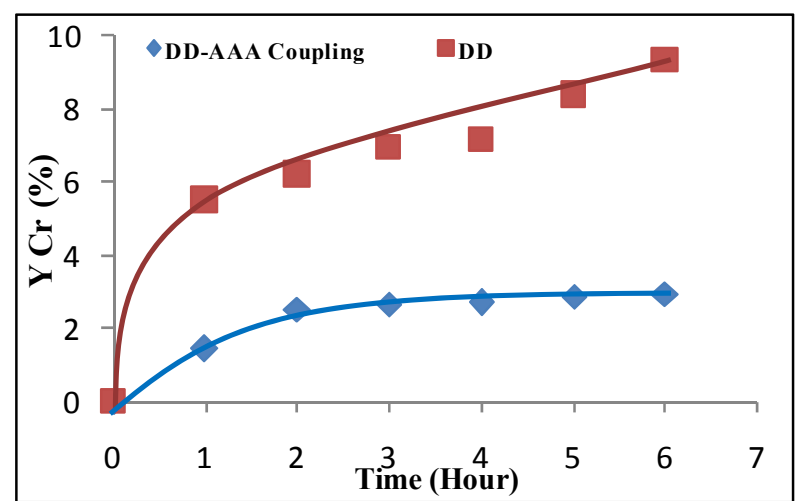

Figure 6. Amount of the chromium (VI) in the receiver compartment with and without DD-AAA coupling.

after 6 hours), there is a small amount of free chromium (VI) (2\% after 6 hours) compared to the case of not coupling. This contributes to maintain the concentration gradient of $\mathrm{Cr}$ (VI) high, therefore improving the kinetics of the process.

\section{Conclusion}

This study shows that the application of Donnan dialysis coupled to adsorption onto activated alumina is a successful and original coupling. This combination allows to improve the efficiency, the kinetics of transmembrane transfer and to reduce the amount of activated alumina to regenerate. The amount of chromium removed is obtained about $90 \%$ in six hours.

\section{REFERENCES}

[1] T. Karthikeyan, S. Rajgopal and L. R. Miranda, "Chromium (VI) Adsorption from Aqueous Solution by Hevea Brasilinesis Sawdust Activated Carbon," Journal of Hazardous Materials, Vol. 124, No. 1-3, 2005, pp. 192-199. doi:10.1016/j.jhazmat.2005.05.003

[2] J. L. G. Torresdey, K. J. Tiemann and V. Armendariz, "Characterization of $\mathrm{Cr}(\mathrm{VI})$ Binding and Reduction to $\mathrm{Cr}(\mathrm{III})$ by the Agricultural Byproducts of Avena Monida (Oat) Biomass" Journal of Hazardous Materials, Vol. 80 No. 1-3, 2000, pp. 175-188. doi:10.1016/S0304-3894(00)00301-0

[3] J. W. Paterson, "Wastewater Treatment Technology," Ann Arbour Science, Michigan, 1975, pp. 43-58.

[4] G. Tiravanti, D. Petruzzelli and R. Passino, "Pretreatment of Tannery Wastewaters by an Ion Exchange Process for Cr (III) Removal and Recovery," Water Science Technology, Vol. 36, No. 2-3, 1997, pp. 197-207. doi:10.1016/S0273-1223(97)00388-0

[5] S. Rengaraj, K. H. Yeon and S. H. Moon, "Removal of Chromium from Water and Wastewater by Ion Exchange Resins," Journal of Hazardous Materials, Vol. 87, No. 1-3, 2001, pp. 273-287. doi:10.1016/S0304-3894(01)00291-6

[6] S. Rengaraj, K. H. Yeon, S. Y. Kang, J. U. Lee, K. W. Kim and S. H. Moon, "Studies on Adsorptive Removal of $\mathrm{Co}(\mathrm{II}), \mathrm{Cr}(\mathrm{III})$ and $\mathrm{Ni}(\mathrm{II})$ by IRN77 Cation-Exchange Resin," Journal of Hazardous Materials, Vol. 92, No. 2, 2002, pp. 185-198. doi:10.1016/S0304-3894(02)00018-3

[7] S. Rengaraj, C. K. Joo, Y. Kim and J. Yi, "Kinetics of Removal of Chromium from Water and Electronic Process Wastewater by Ion Exchange Resins: 1200H, $1500 \mathrm{H}$ and IRN97H," Journal of Hazardous Materials, Vol. 102, No. 2, 2003, pp. 257-275. doi:10.1016/S0304-3894(03)00209-7

[8] D. Petruzzelli, R. Passino and G. Tiravanti, "Ion Exchange Process for Chromium Removal and Recovery from Tannery Wastes," Industrial \& Engineering Chemistry Research, Vol. 34, No. 8, 1995, pp. 2612-2617. doi:10.1021/ie00047a009

[9] F. Gode and E. Pehlivan, "Sorption of Cr (III) onto Chelating b-DAEG-sporopollenin and CEP-Sporopollenin Resins," Bioresource Technology, Vol. 98, No. 4, 2007, pp. 904-911. doi:10.1016/j.biortech.2006.02.043

[10] C. A. Kozlowski and W. Walkowiak, "Removal of Chromium (VI) from Aqueous Solutions by Polymer Inclusion Membranes," Water Research, Vol. 36, No. 19, 2002, pp. 4870-4876. doi:10.1016/S0043-1354(02)00216-6

[11] H. Shaalan, M. Sorour and S. Tewfik, "Simulation and 
Optimization of a Membrane System for Chromium Recovery from Tanning Wastes," Desalination, Vol. 141, No. 3, 2001, pp. 315-324. doi:10.1016/S0011-9164(01)85008-6

[12] G. Ghosh and P. K. Bhattacharya, "Hexavalent Chromium Ion Removal through Micellar Enhanced Ultrafiltration," Chemical Engineering Journal, Vol. 119, No. 1, 2006, pp. 45-53. doi:10.1016/j.cej.2006.02.014

[13] H. Ozaki, K. Sharma and W. Saktaywin, "Performance of an Ultra-Low Pressure Reverse Osmosis Membrane (ULPROM) for Separating Heavy Metal: Effects of Interference Parameters," Desalination, Vol. 144, No. 1-3, 2002, pp. 287-294. doi:10.1016/S0011-9164(02)00329-6

[14] K. A. Matis and P. Mavros, "Recovery of Metals by Ion Flotation from Dilute Aqueous Solutions," Separation and Purification Methods, Vol. 20, No. 1, 1991, pp. 1-48. doi:10.1080/03602549108021407

[15] J. R. Parga, D. L. Cocke, V. Valverde, J. A. G. Gomes, M. Kesmez, H. Moreno, M. Weir and D. Mencer, "Characterization of Electrocoagulation for Removal of Chromium and Arsenic," Chemical Engineering \& Technology, Vol. 28, No. 5, 2005, pp. 605-612. doi:10.1002/ceat.200407035

[16] E. Salazar, M. I. Ortiz and A. M. Urtiaga, "Equilibrium and Kinetics of Cr (VI) Extraction with Aliquat 336," Industrial \& Engineering Chemistry Research, Vol. 31, No. 6, 1992, pp. 1516-1522. doi:10.1021/ie00006a014

[17] M. N. Chen and O. J. N. Hao, "Microbial Chromium (VI) Reduction," Critical Reviews in Environmental Science and Technology, Vol. 28, No. 3, 1998, pp. 219-251. doi:10.1080/10643389891254214

[18] T. Mohammadi, A. Moheb, M. Sadrzadeh and A. Razmi, "Modeling of Metal Ion Removal from Wastewater by Electrodialysis," Separation and Purification Technology, Vol. 41, No. 1, 2005, pp. 73-82. doi:10.1016/j.seppur.2004.04.007

[19] V. K. Gupta, I. Ali, T. A. Saleh, M. N. Siddiqui and S. Agarwal, "Chromium Removal from Water by Activated Carbon Developed from Waste Rubber Tires," Environmental Science and Pollution Research, Vol. 20, No. 3, 2013, pp. 1261-1268. doi:10.1007/s11356-012-0950-9

[20] I. Marzouk, L. Dammak and B. Hamrouni, "Adsorption of Chromium onto Activated Alumina: Kinetics and Thermodynamics Studies," Water Environment Research, Vol. 85, No. 2, 2013, pp. 99-104. doi:10.2175/106143012X13560205144137

[21] D. C. Sharma and C. F. Forster, "Removal of Hexavalent Chromium Using Sphagnum Moss Peat," Water Research, Vol. 27, No. 7, 1993, pp. 1201-1208. doi:10.1016/0043-1354(93)90012-7

[22] D. C. Sharma and C. F. Forster, "A Comparison of the Sorbtive Characteristics of Leaf Mould and Activated Carbon Columns for the Removal of Hexavalent Chromium," Process Biochemistry, Vol. 31, No. 3, 1996, pp 213-218. doi:10.1016/0032-9592(95)00049-6

[23] K. K. Singha, S. H. Hasan, M. Talat, V. K. Singh and S. K. Gangwar, "Removal of Cr (VI) from Aqueous Solutions Using Wheat Bran," Chemical Engineering Journal, Vol. 151, No. 1-3, 2009, pp. 113-121. doi:10.1016/i.cej.2009.02.003

[24] G. Wisniewska, T. Winnicki, "Acidic Wastewater Treatment by Donnan Dialysis Involving Tubular Anion Exchange Membranes," Desalination, Vol. 68, No. 2-3, 1998, pp. 121-130. doi:10.1016/0011-9164(88)80049-3

[25] K. Pyrzynska, "Atomic Absorption Spectrophotometric Determination of Gold with Preconcentration by Donnan Dialysis," Talanta, Vol. 41, No. 3, 1994, pp. 381-386. doi:10.1016/0039-9140(94)80142-8

[26] J. E. DiNunzio and M. Jubara, "Donnan Dialysis Preconcentration for Ion Chromatography," Analytical Chemistry, Vol. 55, No. 7, 1983, pp. 1013-1016. doi:10.1021/ac00258a008

[27] A. Dieye, C. Larchet, B. Auclair and C. Mar-Diop, "Elimination des Fluorures par la Dialyse Ionique Croisée," European Polymer Journal, Vol. 34, No. 1, 1998, pp. $67-$ 75. doi:10.1016/S0014-3057(97)00079-7

[28] M. Hichour, F. Persin, J. Molenat, J. Sandeaux and C. Gavach, "Fluoride Removal from Diluted Solutions by Donnan Dialysis with Anion Exchange Membranes," Desalination, Vol. 122, No. 1, 1999, pp. 53-62. doi:10.1016/S0011-9164(99)00027-2

[29] M. Hichour, F. Persin, J. Sandeaux and C. Gavach, "Fluoride Removal from Waters by Donnan Dialysis," Separation and Purification Technology, Vol. 18, No. 1, 2000, pp. 1-11. doi:10.1016/S1383-5866(99)00042-8

[30] J. Seneviratne, S. D. Holmstrom, J. A. Cox, "Donnan Dialysis Preconcentration Coupled with Ion Chromatography and Electrocatalytic Oxidation for the Determination of Cyanide," Talanta, Vol. 52, No. 6, 2000, pp. 1025-1031. doi:10.1016/S0039-9140(00)00478-1

[31] W. S. H. Ho and K. K. Sirkdar (Eds.), "Dialysis in Membrane," Handbook, Part IV, Van Nostrand Reinhold, New York, 1992.

[32] Y. Cengeloglu, A. Tor, E. Kir and M. Ersoz, "Transport of Hexavalent Chromium through Anion Exchange Membranes," Desalination, Vol. 154, No. 3, 2003, pp. 239-246. doi:10.1016/S0011-9164(03)80039-5

[33] J. Luo, C. Wu, T. Xu and Y. Wu, "Diffusion DialysisConcept, Principle and Applications," Journal of Membrane Science, Vol. 366, No. 1-2, 2011, pp. 1-16. doi:10.1016/j.memsci.2010.10.028

[34] S. T. Hwang and K. Kammermeyer, "Electromembrane Processes Membranes in Separation, Techniques of Chemistry," Wiley/Interscience, New York, 1975.

[35] L. Picincu and D. Pletcher, "The Transport of $\mathrm{Cu}$ (II) Through a Sulfonated Styrene/Divinylbenzene Copolymer Membrane," Journal of Membrane Science, Vol. 147, No. 2, 1998, pp. 257-263. doi:10.1016/S0376-7388(98)00128-8

[36] V. Kislik, A. Eyal, "Aqueous Hybrid Liquid Membrane Process for Metal Separation: Part II. Selectivity of Metals Separation from Wet-Process Phosphoric Acid," Journal of Membrane Science, Vol. 169, No. 14, 2000, pp. 133-146. doi:10.1016/S0376-7388(99)00332-4

[37] D. E. Akretche and H. Kerdjoudj, "Donnan Dialysis of Copper, Gold and Silver Cyanides with Various Anion Exchange Membranes," Talanta, Vol. 51, No. 2, 2000, pp. 
281-289. doi:10.1016/S0039-9140(99)00261-1

[38] K. Pyrzynska, "Membrane Method for Preconcentrating and Separating Gold Complexes from Aqueous Solutions Containing Other Platinum Group Metals," Analytica Chimica Acta, Vol. 255, No. 1, 1991, pp. 169-175. doi:10.1016/0003-2670(91)85103-Y

[39] Y. Yang and P. N. Pintauro, "Multicomponent SpaceCharge Transport Model for Ion-Exchange Membranes," AIChE Journal, Vol. 46, No. 6, 2000, pp. 1177-1190. doi:10.1002/aic.690460610

[40] French standard NF X 45-200, "Membranes Polymers Échangeuse D'ions,” AFNOR, 1995.

[41] H. Strathmann, "Membrane Science and Technology,"
Series Elsevier Ltd., 2004.

[42] L. Dammak, V. Toureuil, C. Larchet and B. Auclair, "Experimental Determination of the Water Flow through Charged Membranes in Bi-Ionic Systems," New Journal of Chemistry, Vol. 21, No. 12, 1997, pp. 1291-1296.

[43] I. Marzouk, C. Hannachi, L. Dammak and B. Hamrouni, "Removal of Chromium by Adsorption on Activated Alumina," Desalination and Water Treatment, Vol. 26, No. 1-3, 2011, pp. 279-286.

[44] I. Marzouk, L. Dammak, L. Chaabane and B. Hamrouni, "Optimization of Chromium (VI) Removal by Donnan Dialysis," American Journal of Analytical Chemistry, Vol. 4, No. 6, 2013, pp. 306-313. doi:10.4236/ajac.2013.46039 